\title{
MAPPING AWARENESS OF HALAL COSMETICS BRANDS IN THE TEENAGERS SEGMENT OF BANDUNG CITY
}

\author{
Muhsin \\ Dosen Prodi Perbankan Syariah \\ FAI Universitas Islam Nusantara Bandung \\ muhsin@uninus.ac.id
}

\begin{abstract}
There are many factors that can explain why the consumer market for halal products is now growing fast, among others, because the profile of the younger generation of Islam is now more religious thanks to the rapid flow of information, awareness, knowledge and concern for halal consumption. One component of brand strength is brand awareness, which is how well consumers know or know about a brand. Therefore, brand awareness is a key determinant of building brand equity. When products are in the early stages of growth, such as halal cosmetics, which are new players in the cosmetics business, brand awareness is important to encourage this growth. The first research problem departed from the central phenomenon of how teenagers actually aware of halal cosmetics in the city of Bandung, and which halal cosmetic brands are best known? Associated with the issue of brand strength, then more specifically the problem of this research is how strong are teenagers aware of some halal cosmetic brands that are circulating in the city of Bandung, high, medium or low? Then is this brand awareness related to consumer demographic factors? Then is this brand awareness related to loyalty to halal cosmetic brands? The results showed that adolescents in the city of Bandung who require to use cosmetics labeled halal because they are aware of religious values, one of which as a form of Islamic law is included in rational instrumental actions. Then interpret cosmetics labeled halal as a form of carrying out Islamic law because it is protected from material that is haram and will not affect worship. Teenagers in Bandung City who are not based on using cosmetics labeled halal because they prefer cosmetics based on their needs and price and quality are included in instrumental rational actions. Then interpret halal labeled cosmetics as cosmetics that are safe for the skin because they do not cause irritation, cosmetics that are protected from prohibited ingredients, cosmetics that have no difference with other cosmetics.
\end{abstract}

Keywords: Cosmetics, halal, brand awareness, teenagers

\section{A. INTRODUCTION}

The cosmetics industry in Indonesia is growing rapidly from year to year, and is now starting to be noticed by various parties. Call it the Beauty Market Survey (BMS), which uses data from Nielsen and Euro Monitor, reporting that the value of the Indonesian cosmetic industry is estimated to reach 36 trillion rupiah (USD \$ 2.7 billion) in 2016 or an increase of 12 percent over the previous year (Indonesia- Investment, 2017). Based on data from the Ministry of Industry (2016), this industry market growth averaged $9.67 \%$ per year in the last six years (2009-2015). It is estimated that the market size of the cosmetics market is Rp. 46.4 trillion in 2017. With this amount, Indonesia is a potential market for beauty industry entrepreneurs 
both from outside and inside the country (Sigma Research, 2017). The exports are also high, reaching USD818 million or around Rp11 trillion in 2015 (Manufacturindo, 2016). With a population of around 255 million, with almost half the population of women, making Indonesia a promising market for cosmetic companies. That is why CosmeticDesign-Asia.com estimates that Indonesia will become the top 10 global market for skin care cosmetics (US Commercial Services, 2015).

Noting the role and position of the cosmetics industry in Indonesia, it is not surprising if the government includes this industry in the national industry development priority plan until 2019. The reason is, first, because the cosmetics industry is positioned as an import substitution industry, because most of its raw materials are still imported). The import value of both raw materials and machinery reached approximately USD 441 million in 2015. However, compared to the higher export value, the cosmetics industry still has a surplus of around $85 \%$. Second, is to increase employment opportunities for the local community. The cosmetics industry includes labor-intensive industries, and so far it is estimated that it can absorb 75,000 direct workers and 600,000 indirect workers (Manufacturindo, 2016). Although the cosmetics market is quite large, the challenges are also large, including differences in consumer characteristics. This means that producers must choose several or if they have sufficient resources to make all segments as their target market. Another obstacle is related to business problems, namely the matter of regulation, licensing bureaucracy, inappropriate areas of authority, the amount of smuggling, and the rise of illegal cosmetics (Economics and Business, 2017). The positive prospects of the cosmetics business in Indonesia are also marked by the emergence of local brands, including the household cosmetics industry or salons, so that the competition continues to be tighter. Some of the big companies in this industry include PT Unilever Indonesia, PT Mandom Indonesia, PT Mustika Ratu, PT Akasha Wira International, PT Martina Berto, Paragon Technology \& Innovation, and L'Oreal. The subsector growth in the cosmetics industry in Indonesia is no doubt a lot of inviting new entries, both from outside and within their own country. Currently there are an estimated 760 cosmetic companies in Indonesia (Manufacturindo, 2016), and up to 2012 there have been 9,000 registered types of cosmetics, or larger than food products and other household products (Cekindo, 2016).

Because the cosmetic market in Indonesia is very prospective, the entry of imported cosmetic products is unavoidable. The results of research conducted by Nielsen, based on beauty product sales data in the third quarter of 2015, 48 percent of consumers like global brand cosmetics, 36 percent choose local products, and the remaining 16 percent do not have any preferences (KataData: News \& Research, 2016). The demand for imported Indonesian cosmetics continues to increase along with the growth in the need for premium cosmetic brands from middle-class consumers in Indonesia.

The heavy import of cosmetics entering Indonesia raises concerns for Muslim consumers because the aspects of halalness are doubtful. Unlike food, cosmetics are not absorbed directly by the body. Some cosmetic raw materials which are halal critical points include fat, collagen, elastin, placenta extract, vitamin stabilizers, alpha hydroxyl acids, and hormones. These ingredients are very vulnerable because they can be derived from animal fats that are forbidden such as pigs, dogs, wild animals, blood, carcasses, and alcohol.

Some people still question why it must be halal? Isn't cosmetics not eaten as intended in religious orders. Even though the provisions of Islamic law include halal, haram and unclean 
aspects, both Najis Mukhaffafah (mild), Najis Mutawassithah (moderate) and Najis Mughallazhah (heavy). If then the unclean sticks to one of the limbs, then it can affect the validity of the worship carried out by a Muslim. Thus, halal cosmetics are the answer especially for Muslim women who want to look beautiful but do not violate religious teachings.

The halal cosmetic phenomenon in Indonesia was first captured and spearheaded by the Wardah brand, and the result after 15 years (2010 to 2011), the products it sold increased by 20 percent to more than 10 million units. Next sales increase 50 percent each year. Wardah's sales figures now reach around IDR 200 billion per month in 2014, or far exceeding Mustika Ratu and Martha Tilaar product sales, which are only in the range of 400 and 600 billion rupiah a year (Handayani, 2016). Not only domestic cosmetics brands, foreign products are sensitive to changes in consumer preferences.

An example is Garnier from L'oreal and Unilever which has guaranteed the halal quality of many of its products. Although there is no halal label on the packaging, the products of this company have already obtained halal certificates from the MUI Food and Drug Research Institute (LPPOM). Data from LPPOM MUI noted that in 2016 there were 48 companies with a total of 5,254 halal cosmetic products and in 2017 there were 64 companies with a total of 3,219 products. As of March 2018, there have been 41 companies with a total of 2,115 halal certified products (Juniman, 2018). The majority of Indonesian Muslims who are expected to encourage increased demand for halal cosmetics. The report on future market insight (FMI) in September 2015, estimates that the halal cosmetics market in Southeast Asia including Indonesia will grow an average of 9.9 percent in the $2015-2020$ period (US Commercial Services, 2015).

In Indonesia, halal cosmetic reference is the recognition of halal in the form of halal certificates from LPPOM MUI after going through a series of audit stages from MUI, both the assessment of raw materials and the manufacturing process including the quality control process, equipment, buildings and personnel involved in the production of cosmetics. This institution is tasked with researching, analyzing, analyzing and deciding whether products both food and its derivatives, medicines and cosmetics are safe for consumption both in terms of health and from the side of Islam that is halal or permissible and good for consumption for Muslims especially in territory of Indonesia. Halal certificate is a written fatwa stating the halalness of a cosmetic brand according to Islamic provisions covering materials to the production process. This halal certificate is important to ensure that the body is not contaminated with ingredients that are forbidden by Islam. as well as being a determinant of worship of a Muslim accepted by Allah SWT. For producers, halal certification is a form of commitment and responsibility of the company to provide quality products, safe and comfortable to use especially for Muslim consumers in Indonesia

Many factors influence the purchase decision of halal cosmetics, one of which is Islamic theological considerations which instruct every Muslim to choose the consumption of halal and thayyib (good) and stay away from the forbidden, to maintain physical and spiritual health. In Al-Quran Al-Nahl verse 114 explained "Then eat the lawful good from the sustenance that Allah has given you; and thank Allah's favor if you only worship Him. " In this verse Allah has commanded humans to only eat (consume) halal food. If applied in this context, the paragraph applies not only to food, but also to other products that can be consumed by humans, including cosmetics. 


\section{B. METHOD}

This study uses a mixed methods research (MMR) design. In general mixed methods is a procedure of collecting, analyzing and mixing or integrating quantitative and qualitative data at several stages of the process in a research project to obtain a more complete understanding of the problem of the proposed research (Tashakkori and Teddlie 2003; Creswell 2014). The rational approach is that a general description of the awareness of halal cosmetic brands obtained based on quantitative data is then analyzed in more depth based on the support of qualitative data.

More specifically, this study uses Sequential Explanatory Mixed Methods Research Design with greater priority or weight on the quantitative approach, and carried out in the first stage. In the first stage, a quantitative approach was intended to measure and map brand awareness and loyalty to halal cosmetics in the adolescent age group and its relationship with several relevant factors. The results are then used to analyze the competition map of the halal cosmetics business based on aspects of brand awareness. The results are then explained or deepened by the qualitative approach carried out in the second stage. The findings obtained from the second stage will be taken into consideration to confirm and clarify the findings revealed from the quantitative approach in the previous stage. The qualitative analysis phase will identify important themes that can explain in more depth, more insights on some findings in quantitative analysis.

\section{RESULT AND DISCUSSION}

The concept of brand awareness in this study is Top of Mind (TOM), which is a brand or halal cosmetic brand that was first mentioned by respondents, and is in a special position. More technically, awareness of halal cosmetic brands was asked by respondents whether they were familiar with one of the halal cosmetic brands for skin care. In a simple sense, the brand is the leader in the minds of consumers compared to the names of other brands. Top of mind reflects the value of mind share from the customer, namely the strength of a particular brand in the minds of consumers of certain product categories. The brand is relative to its competing brands. The higher the value of the mind share of a brand, the stronger the brand will be.

The top of mind halal cosmetics position, in general, be explained by the following picture. Approximately $74 \%$ of respondents stated that they were familiar with the six categories of halal cosmetic brands that were submitted (attachment 3). The extent to which they know it and why they do not know it, will be expressed through a qualitative descriptive approach (QDA). 


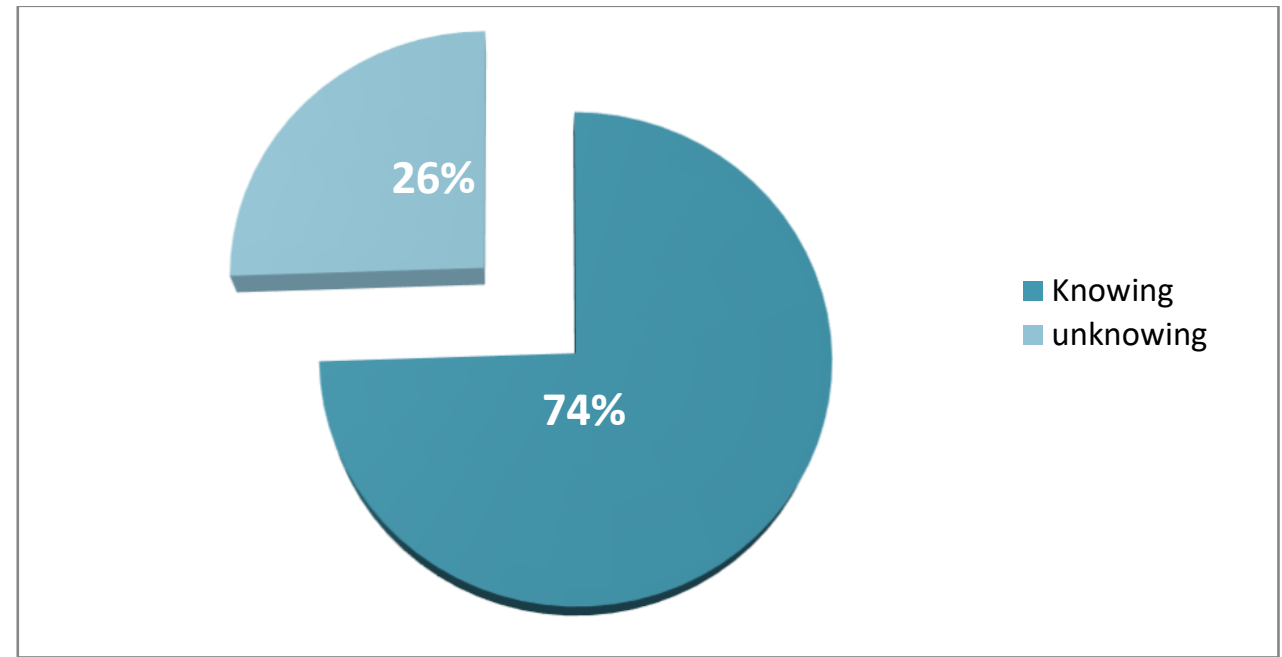

Picture 1

Distribution of respondents according to brand awareness of halal cosmetics

Whereas if it is specified based on the type of cosmetics, brand awareness of halal moisturizers / hand bodies is in the top rank ( $83 \%)$, followed by foundation / foundation $(77 \%)$ and bath soap $(76 \%)$. While face freshener / toner is in the lowest rank $(69 \%)$. The three best known types of cosmetics are allegedly because they are most often used every day.

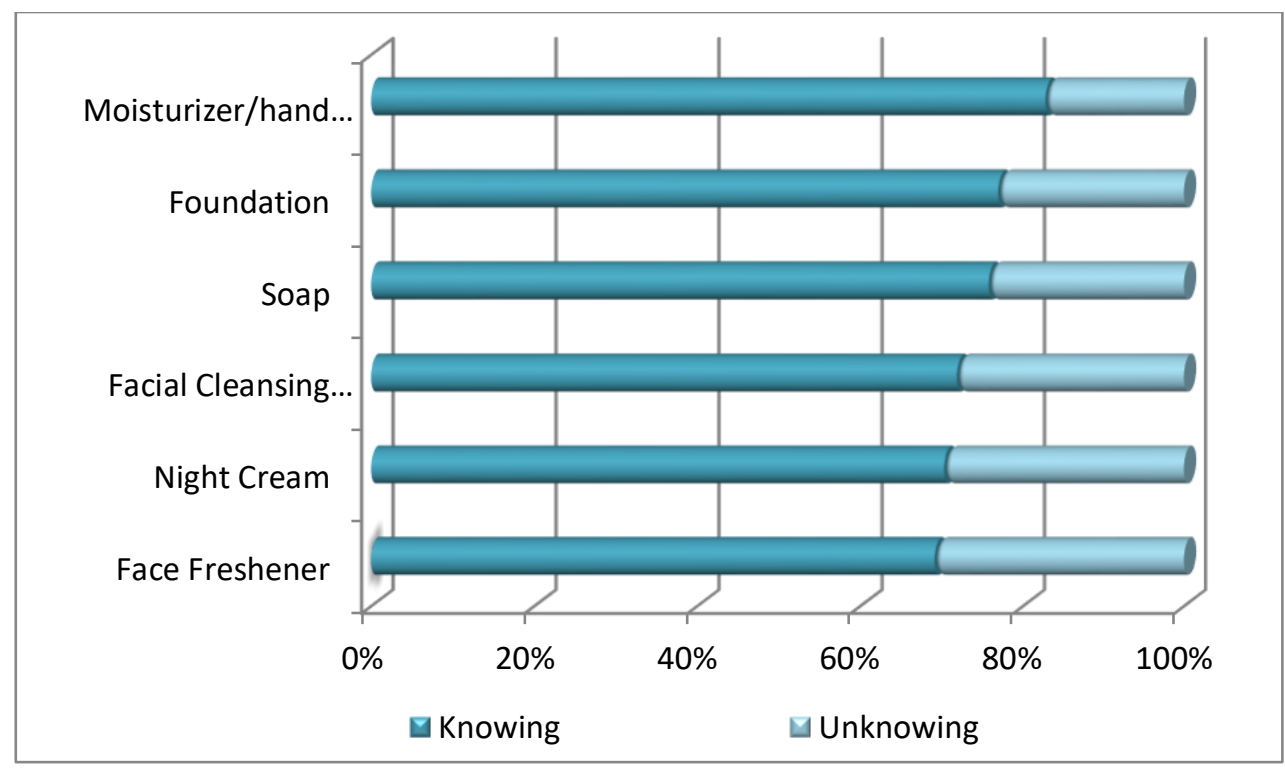

Figure 2

Distribution of awareness of halal cosmetic brands by type

Not only knowing, but also most of the respondents claimed to use halal cosmetics, or means that halal cosmetics have been accepted by the general public as an alternative to cosmetics which is not yet clear halal. Approximately $74 \%$ of respondents claimed that most of the cosmetics they used were believed to be halal. In terms of age, most of the respondents $(79 \%)$ came from the age group 19-21 years (attachment 4). Although further research is still needed, there are indications that the higher the age, the higher public awareness to use 
halal cosmetics. This trend is understandable considering that the more mature age, rationality and theological arguments about the halalness of an item are more easily accepted. On the contrary, only about $2 \%$ of respondents claimed that none of the halal cosmetics they used were classified as halal.

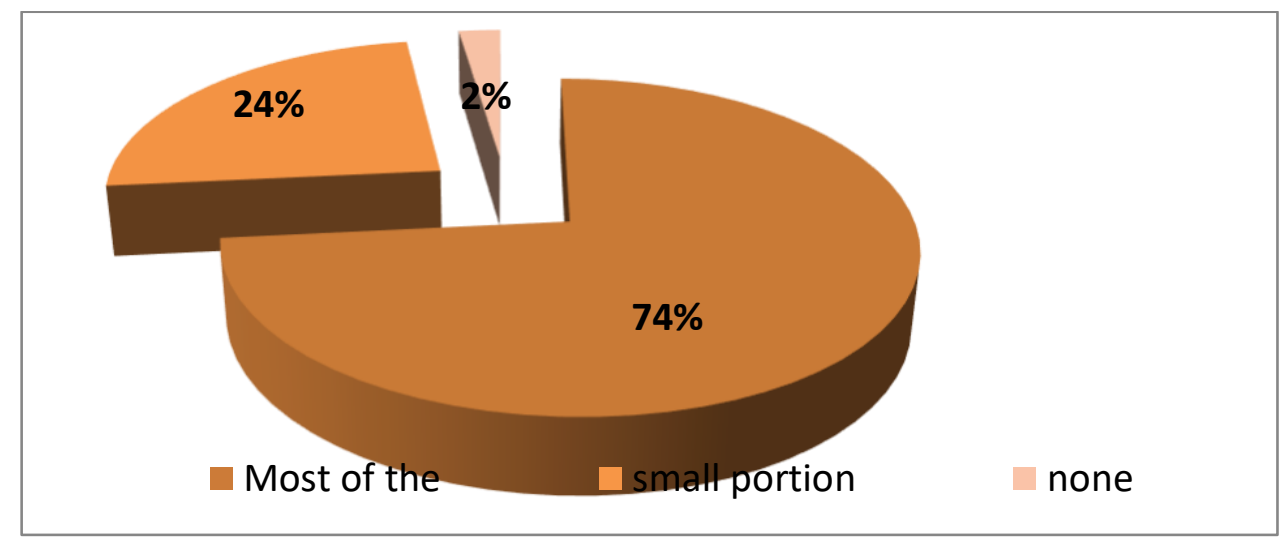

Figure 3.

Proportion of the use of halal cosmetics

They believe that halal cosmetics that have been certified by the MUI, in fact the main reference $(75 \%)$ is seeing / reading from packages bearing the MUI logo. This trend is not much different from the findings of Mahiranissa \& Hudrasyah (2015) study in Bandung, which revealed that approximately $95.5 \%$ of respondents claimed to be confident about the halalness of a product if there was a MUI Halal logo on the packaging. The results of the Baig \& Baig (2014) study in Pakistan also revealed the same thing, namely the interest of consumers to buy halal cosmetics determined by the halal logo listed in the packaging.

On the one hand it was very encouraging because the MUI Halal logo was trusted by the community, but on the other hand it was rather worrying if later the logo was misused / falsified by irresponsible producers. Therefore, the supervision of the MUI is very important for the avoidance of the public from the possibility of using cosmetics that are not clearly halal. The results of other studies also reported that there was a moderate and positive relationship between awareness of halal brands and their perceptions of Halal certification (Mashitoh, Rafida, \& Alina, 2013). Second place after packaging, the source of halal information believed by the respondents was MUl's website (http://www.halalmui.org). This tendency suggests to the MUI to always update its pages to avoid losses for the consumers and producers. 


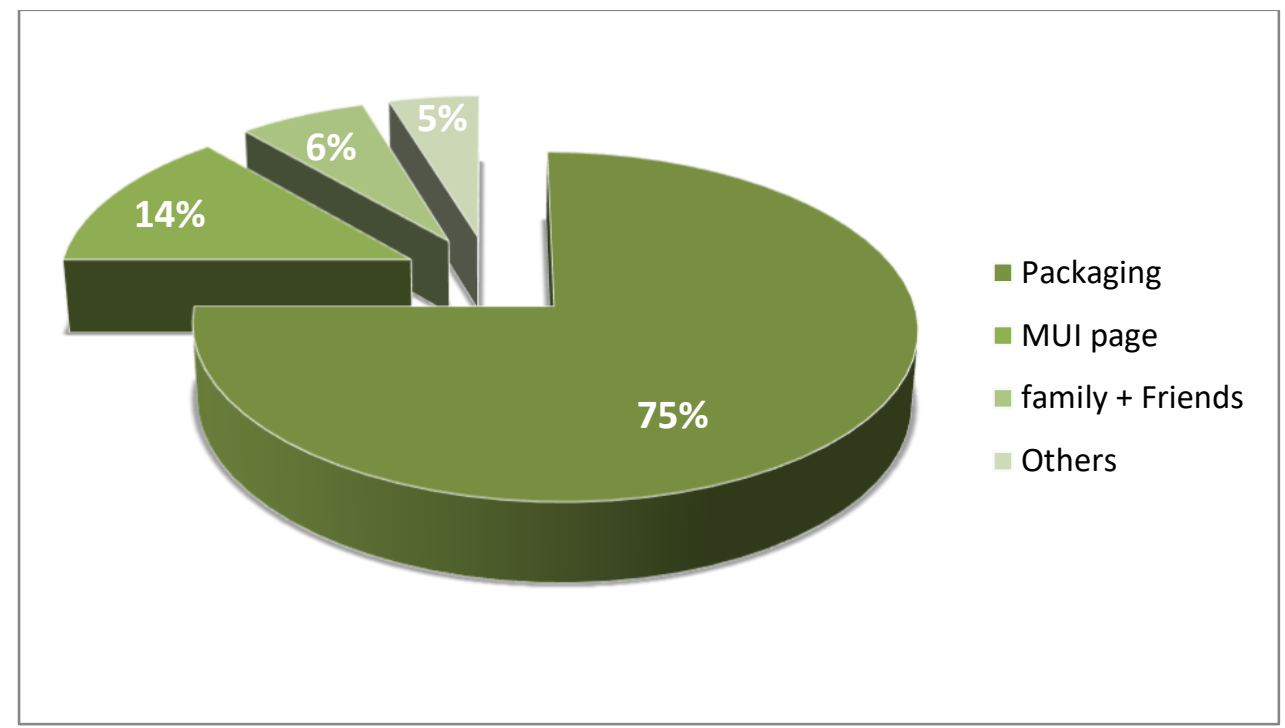

Figure 4.

The source of halal cosmetic information

Not necessarily consumers who are aware of a particular product brand are followed by actual purchace of the product. More steps are needed to get to the purchase stage. There are at least two more stages that must be passed, namely brand consideration and then being selected as a brand preference. Flow brand awareness - brand consideration - this brand preference is known as the hierarchical path or sales funnel (Foster, 2018). This study also revealed that of all respondents who were familiar with halal cosmetics, there were $19 \%$ who did not use halal cosmetics they knew. Although the number is relatively small, this phenomenon is interesting to explore, what factors cause it, will be explored with a qualitative approach.

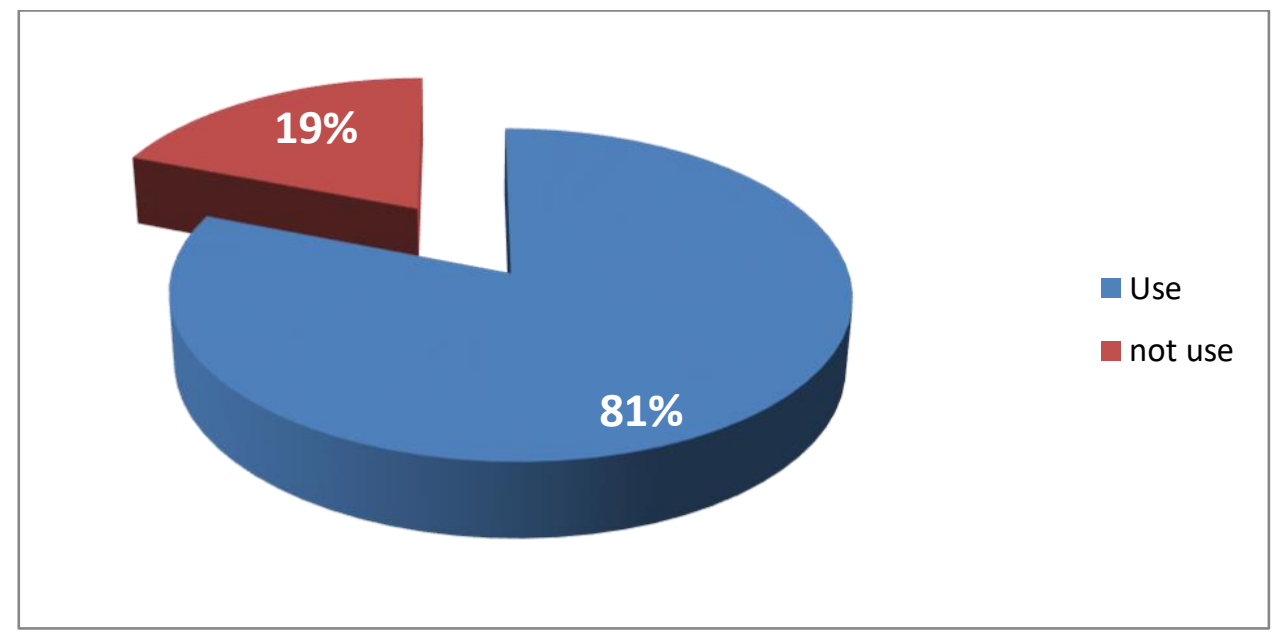

Figure 5

Distribution of respondents who know the brand and use it 
Bath soap is the best known and most widely used category of halal cosmetic products, while the lowest is foundation powder which is approximately $30 \%$ not using it even though it knows it.

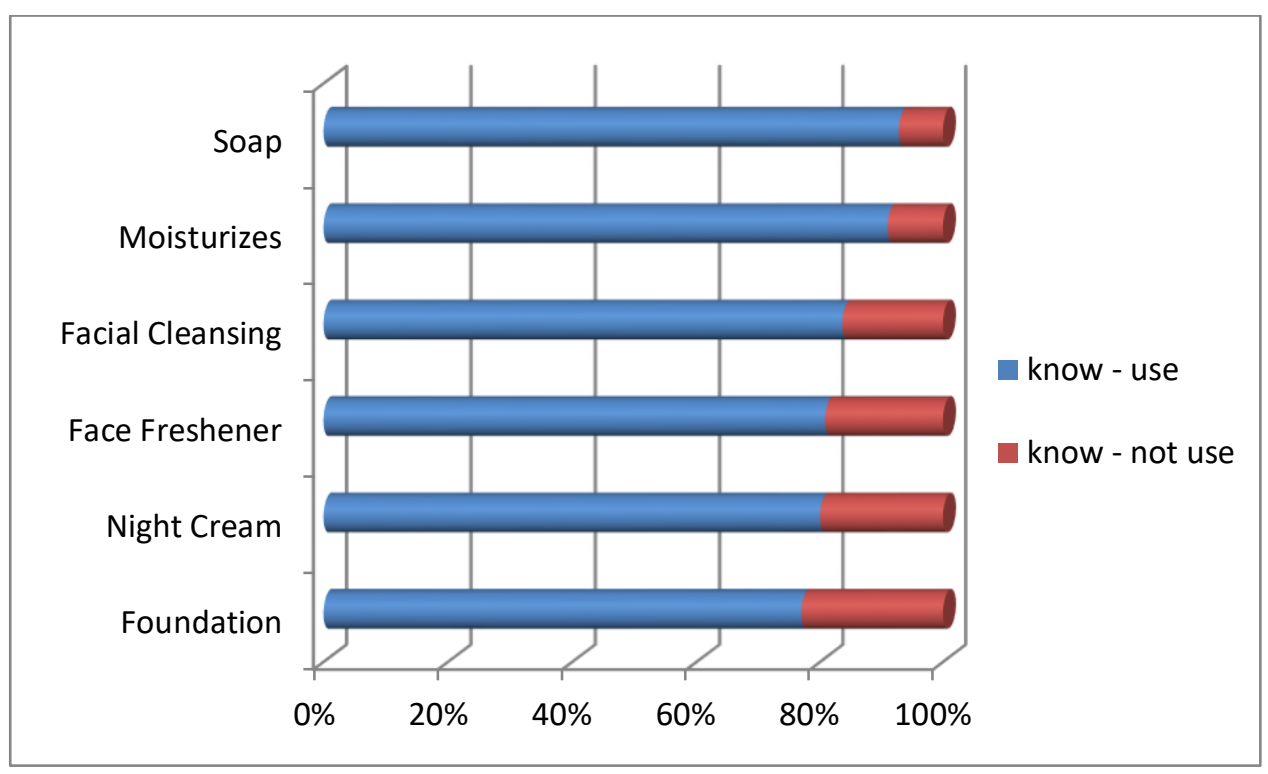

Figure 6

Distribution of respondents who know the brand and use it according to its type

As explained in the Lavidge-Steiner Traditional Order hierarchy of Effect model, brand awareness is a new initial stage that can direct consumer choices to a particular product category. Many ads are seen and heard by consumers every day, but little is remembered. The second stage is to find out about the products they know, whether through friends, relatives, the internet or directly seeking information from the seller.

Product knowledge includes at least the attributes of price, taste, raw materials, packaging, nutritional content and others. When consumers don't get clear information, they will quickly switch to finding other brands. At this stage, the company's obligation is to prepare product information as easily and quickly as possible. In the third stage, based on an evaluation of the information obtained, it will encourage consumers to like / dislike the product (liking). Because it is certain that consumers do not like just one brand, then in the fourth stage is choosing and collecting some of the brands they like in one preference list that they will consider if they plan to buy the product. In the fifth stage, consumers begin to solidify their hearts to choose one of the brands entered in their preferences (conviction), and continue with the sixth stage, namely the purchase process (purchase). Phase one and two belong to the cognitive area of consumers, stages three and four enter the affective region of consumers, and stages five and six enter the conative region of consumers. 
Then when detailed by brand, it is mapped that "Wardah" is the most recognized halal cosmetic brand, at least for the types of facial cleansing cosmetics, facial fresheners, night creams and foundation. This can be understood, as described earlier, Wardah is a cosmetic brand that first declared as halal cosmetics in Indonesia. While the Lifebouy and BDL brands are the best known in the category of bath and moisturizers / hand bodies.

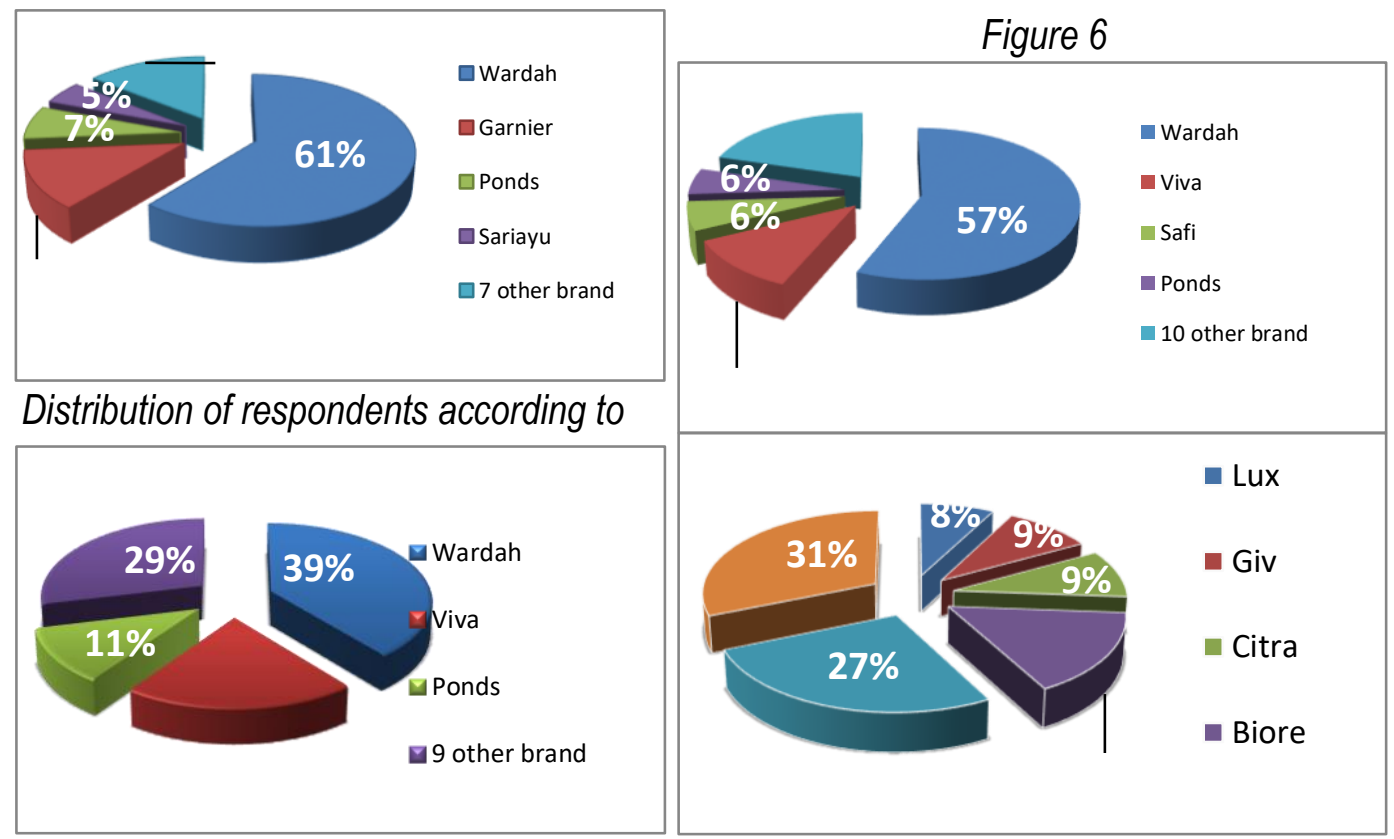

the most popular cosmetic brands

In general, the level of awareness of halal cosmetic brands has a positive, close and significant relationship with loyalty to the brand. This indicates that (ceteris paribus), the higher the teenager's awareness of the halal cosmetic brand, the greater the chance for him to use it continuously.

This study revealed that overall aspects of halal were ranked second (recognized as the first consideration by approximately $28.9 \%$ of respondents) after the price factor was one of the factors considered by the public when choosing a type or brand of cosmetics. This finding is slightly different from that reported by Sigma Research (2017), the biggest factor in the presentation is the compatibility of the formula on the skin, followed by products that are durable, lightweight formulas, color, halal, and price.

It seems that the issue of cosmetics is now increasingly developing not only in terms of quality and safety but far deeper in its aspects of halalness. The urgency of halal cosmetics is absolute, especially for Muslim women who of course in all aspects of their daily life have guidelines that halalness is very important. Most respondents (74.3\%) placed halality as the main factor considered when choosing cosmetics were respondents in the 19-21-year age group. Again, this indicates that the higher the age, the higher public awareness to use halal cosmetics. However, because the price factor ranks first considered by the community in choosing cosmetics, it is likely that this price factor will have a negative effect on public awareness in using halal cosmetics, especially for those who are classified as having a level 
of confidence that is not yet solid. Based on Cramer's V test, it was found that there was no relationship between age and occupation with consideration factors in choosing cosmetics (P-values> 0.05). This means that the price and halal factors remain as the first and second considerations in choosing cosmetics, and are not determined by age and employment status. But when it is related to the level of income / pocket money of the respondents, it turns out to be significantly related ( $P$-values $<0.05$ ). It is a fact that can be understood when the higher the income, the factor of price is no longer the first consideration.

The behavior of changing brand-changing cosmetics is reasonable when associated with compatibility and security considerations. This is understandable considering that not all cosmetics are suitable for everyone, and not all cosmetic brands (with different types) fit on someone's skin. The compatibility of the formula on the face is a major consideration for choosing cosmetic products by women in all age segments. However, it is also possible to change cosmetic brands due to other factors, such as trends, prices, colors and so on. Too often changing cosmetics will cause the skin to become allergic, irritation to the skin, redness, itching and rough surface. Not only does it sometimes change cosmetics, it will also cause acne problems and can become black spots that are imprinted (Jitu News, 2015).

This study revealed that the majority of respondents (82\%) were classified as frequent and rarely changing brands, and this behavior was dominated (68\%) by the age group 19-21. In contrast to other findings which state that usually teenage women tend to often change cosmetics brands to find the right brand and type (Midori, 2015). This mutually changing brand behavior in some marketing literature is known as the brandswitching concept, a natural symptom in consumer behavior. Brand switching is supported by globalization of information networks, so that catalogs or information on an item can be easily obtained from mass media and electronic and internet advertising. However, statistically there was an association between age and brand change-change behavior ( $P$-values $>0.05)$. Conversely, when associated with employment status and income, each of them is significantly associated with brand change-change behavior. The biggest Cramer's $V$ coefficient is shown by its relationship with the level of income, or there is an indication that the higher the level of income / pocket money obtained the greater the frequency for changing cosmetic brands.

\section{CONCLUSION}

1. In general, the level of awareness of halal cosmetic brands among adolescents in the city of Bandung is positively and closely related to loyalty to the brand. This indicates that (ceteris paribus), the higher the teenager's awareness of the halal cosmetic brand, the greater the chance for him to use it continuously.

2. This research reveals that overall aspects of halal rank second (recognized as the first consideration by approximately $28.9 \%$ of respondents) after the price factor as one of the factors considered among adolescents in the city of Bandung when choosing a type or brand of cosmetics.

3. Most respondents $(74.3 \%)$ who place halalness as the main factor considered when choosing cosmetics are respondents in the 19-21-year age group. Again, this indicates that the higher the age, the higher public awareness to use halal cosmetics. However, because the price factor ranks first considered by the community in choosing cosmetics, it is likely that this price factor will have a negative effect on public awareness in using 
halal cosmetics, especially for those who are classified as having a level of confidence that is not yet solid.

4. Replace-changing behavior of cosmetic brands is a fairness for adolescents in the city of Bandung when associated with compatibility and security considerations. This is understandable considering that not all cosmetics are suitable for everyone, and not all cosmetic brands (with different types) fit on someone's skin. The compatibility of the formula on the face is a major consideration for choosing cosmetic products by women in all age segments. However, it is also possible to change cosmetic brands due to other factors, such as trends, prices, colors and so on. Too often changing cosmetics will cause the skin to become allergic, irritation to the skin, redness, itching and rough surface. Not only does it sometimes change cosmetics, it will also cause acne problems and can become black spots that are imprinted (Jitu News, 2015).

5. This study reveals that the majority of respondents (82\%) are classified as frequent and rarely changing brands, and this behavior is dominated (68\%) by the age group 19-21. This mutually changing brand behavior in some marketing literature is known as the brandswitching concept, a natural symptom in consumer behavior. Brand switching is supported by globalization of information networks, so that catalogs or information on an item can be easily obtained from mass media and electronic and internet advertising. However, statistically there was an association between age and brand change-change behavior (P-values> 0.05). Conversely, when associated with employment status and income, each of them is significantly associated with brand change-change behavior. The biggest Cramer's $V$ coefficient is shown by its relationship with the level of income, or there is an indication that the higher the level of income / pocket money obtained the greater the frequency for changing cosmetic brands.

\section{REFERENCES}

Aaker, D. (1991). Managing Brand Equity. New York: Free Press.

Aaker, D. A. (1996). Measuring Brand Equity Across Products and Markets. New York, NY: Free Press.

Alzeer, J., \& Hadeed, K. A. (2016, December). Ethanol and its Halal status in food industries. Trends in Food Science \& Technology, 58, 14-20.

American Marketing Association. (n.d.). American Marketing Association. Retrieved June 2017, from https://www.ama.org/academics/Pages/Model-PredictiveMeasurements-Advertising-Effectiveness.aspx

Amstrong, G., \& Kotler, P. (2015). Marketing: An introduction (12 ed.). Edinburgh Gate: Pearson. 
Anselmsson, J., Johansson, U., \& Persson, N. (2007). Understanding Price Premium for Grocery products: A conceptual model of customer-based brand equity. Journal of Product \& Brand Management, 16(6), 401-414.

Ariawanti, M. (2011, November 07). Jumat 07 November 2014 11:00 WIB. Retrieved November 29, 2018, from https://www.republika.co.id/berita/koran/dialogjumat/14/11/07/nenhso43-hukum-alkohol-dalam-kosmetik

Asrianti, S. (2018, April 12). Republika. Retrieved Desember 3, 2018, from republika.co.id: https://www.republika.co.id/berita/gaya-hidup/trend/18/04/12/p7288h284-psikologungkap-penyebab-remaja-kecanduan-kosmetik

Boulding, W., Kalra, A., Staelin, R., \& Zeithaml, V. A. (1993). A Dynamic Process Model of Service Quality: From Expectations to Behavioral Intentions. , 30(1), 7. Journal of Marketing Research, 30(1), 7-27.

Braun, V., \& Clarke, V. (2006). Using thematic analysis in psychology. Qualitative Research in Psychology, 3(2), 77-101.

Burmeister, E., \& Aitken, L. M. (2012). Sample size: how many is enough? Australian Critical Care, 25(4), 271-274.

Cekindo. (2016). http://www.cekindo.com/.

Cooper, D. R., \& Schindler, P. S. (2014). Business Research Methods (Twelfth ed.). New York: The McGraw-Hill Companies, Inc.

Creswell, J. W. (2014). Research Design: Qualitative, Quantitative, \& Mixed Methods Approaches (4th ed.). London: Sage Publications, Ltd.

Dharmmesta, B. S., \& Handoko, H. (2003). Manajemen Pemasaran: Analisis Perilaku Konsumen. Yogyakarta: BPFE.

Ekonomi dan Bisnis. (2017, April 25). Tribun Bisnis. Retrieved from http://surabaya.tribunnews.com/2017/04/25/industri-kosmetik-pilih-garap-pasarlokal-daripada-ekspansi-ke-luar-negeri

Elliott, R., \& Timulak, L. (2015). Descriptive and interpretive approaches to qualitative research. In J. Miles, \& P. Gilbert, $A$ handbook of research methods for clinical and health psychology (p. 147). Oxford University Press.

Fornell, C. (1992). A National Customer Satisfaction Barometer: The Swedish Experience. Journal of Marketing, 56(1), 6-21. 
Foster, S. (2018, Pebruari 13). Marketing IQ. Retrieved Desember 04, 2018, from marketingiq.co.uk: https://www.marketingiq.co.uk/understanding-brandawareness-consideration-and-preference/

Guest, G., Bunce, A., \& Johson, L. (2006). How many interviews are enough? An experiment with data saturation and variability. Field Methods, 18(1), 59-82.

Handayani, M. S. (2016, Juli 07). Retrieved from Tirto.id: https://tirto.id/kala-kosmetik-halaljadi-jawara-pasar-brvB

Hawkins, D. I., \& Mothersbaugh, D. L. (2010). Consumer behavior: building marketing strategy. New York: McGraw-Hill/lrwin.

Jacob, J., \& Chestnut, R. W. (1978). Brand Loyalty, Measurement and Management. Journal of Advertising, 8(2).

Jitu News. (2015, September 25). Retrieved from http://www.jitunews.com/read/22090/awas-ini-risiko-yang-mengancam-bila-seringgonta-ganti-kosmetik

Juniman, P. T. (2018, Jumat 03). Retrieved from www.cnnindonesia.com: https://www.cnnindonesia.com/gaya-hidup/20180329232035-277287005/mengenal-ketentuan-kosmetik-berlabel-halal-dari-lppom-mui

Kardes, F. R., Conrey, M. L., \& Cline, T. W. (2011). Consumer behavior. Mason, USA: South-Western Cingage Learning.

KataData: News \& Research. (2016, November 17). Konsumen Indonesia Lebih Suka Merek Kosmetik Global. Retrieved from https://databoks.katadata.co.id/datapublish/2016/11/17/konsumen-indonesia-lebihsuka-merek-kosmetik-global

Keller, K. L. (2002). Strategic brand management: Building, measuring and managing brand equity (2nd ed.). Upper Saddle River, NJ: Pearson Education.

Keller, K. L. (2013). Strategic brand management: Building, measuring, and managing brand equity (4 ed.). Harlow: Pearson.

Kementerian Perindustrian RI. (2012, September). http://www.kemenperin.go.id/artikel/5285/Penjualan-Elektronik-Ditaksir-Rp-30Triliun.

Kimpakorn, N., \& Tocquer, G. (2010). Service brand equity and employee brand commitment. Journal of Services Marketing, 24(5), 378-388. 
Kotler, P., \& Keller, K. L. (2016). A framework for marketing management. Edirnbugh Gate, England: Pearson Education.

Kotler, P., \& Pfoertsch, W. (2010). Ingredient branding: Making the invisible visible. London: Springer Heidelberg Dordrecht.

Kotler, P., Amstrong, G., Sander, J., \& Wong, V. (2005). Principle of marketing (4th ed.). European Edition: Prentice Hall.

Kurtz, D. L. (2008). Contemporary marketing (13rd ed.). South-Western: Cengage Learning.

Lemon, K. N., Rust, R. T., \& Zeithaml, V. A. (2001). What Drives Customer Equity? Marketing Management, 20-25.

Lincoln, Y. S., \& Guba, E. G. (2013). The Constructivist Credo. Walnut Creek: Left Coast Press, Inc.

Mahiranissa, A., \& Hudrasyah, H. (2015). DEGREE OF AWARENESS, FOOD SAFETY, AND HEALTH CONSCIOUSNESS; THE IMPACT ON CONFIDENCE TOWARDS MUI'S HALAL LOGO (THE EVIDENCE FROM BANDUNG). Journal of Business \& Management, 4(4), 476-483.

Manufacturindo. (2016, Juni 06). Retrieved from https://manufakturindo.com/news/detail/apa-kabar-industri-kosmetik-indonesia1.html

Mashitoh, A. S., Rafida, A. N., \& Alina, A. (2013). Perception Towards Halal Awareness and its Correlation with Halal Certification among Muslim. Middle-East Journal of Scientific Research 13.

Merriam, S. B., \& Tisdell, E. J. (2016). QUALITATIVE RESEARCH: A Guide to Design and Implementation (fourth ed.). San Francisco: Jossey-Bass.

Midori. (2015, Juni 16). beautynesia. Retrieved 12 17, 2018, from http://beautynesia.id: http://beautynesia.id/2149

Mowen, J. C., \& Minor, M. (2002). Perilaku konsumen (Edisi 5 ed., Vol. 1). Jakarta: Erlangga.

Neergaard, M., Olesen, F., Andersen, R., \& Sondergaard, J. (2009). Qualititative description-The poor cousin of health research. BMC Medical Research Methodology, 9(52). 
Neuman, W. L. (2014). Social Research Methods: Qualitative and Quantitative Approaches (7th ed.). Harlow: Pearson Education Limited.

Ningsih, Y. F., \& Widiyarti, Y. (2018, April 17). Tempo. Retrieved November 30, 2018, from cantik.tempo.co: https://cantik.tempo.co/read/1150862/priyanka-chopra-dan-nickjonas-menikah-dengan-2-tradisi-dan-agama

Norafni, Shafii, Z., \& Shahwan, S. (2015). AWARENESS AND PERCEPTION OF MUSLIM CONSUMERS ON HALAL COSMETICS AND PERSONAL CARE PRODUCTS. International Journal of Business, Economics and Management, 2(1), 1-14.

Osenton, T. (2002). Customer share marketing. New Jersey: Prentice Hall.

Oskamp, S., \& Schultzs, P. W. (2004). Attitudes and opinions (3rd ed.). New York: Lawrence Erlbaum Associate, Inc.

Patton, M. Q., \& Cohran, M. (2007). Qualitative research methodology. A Guided to Using. Medecins San Frontieres.

Peter, J. P., \& Olson, J. C. (2010). Consumer behavior and marketing strategy (9th ed.). New York: The McGraw-Hill Companies, Inc.

Purwanto, S. (2018, Agustus 28). Retrieved November 29, 2018, from adevnatural: https://adevnatural.com/kosmetik-haram-menurut-mui-ketentuan-hukum-danrekomendasi-mui/

Putri, S. (2018, Maret 29). Wolipop. Retrieved Desember 12, 2018, from wolipop.detik.com: https://wolipop.detik.com/hijab-update/d-3943835/kata-muisoal-alasan-wanita-muslim-harus-pakai-kosmetik-halal

Rareş, O. D. (2014). Measuring Perceived Service Quality Offline vs. Online: A New PeSQ Conceptual Mode. Procedia Economics and Finance, 15, 538-551.

Sandelowski, M. (2010). What's in a name? Qualititative description revisited. Research in Nursing \& Health, 33, 77-84.

Savin-Baden, M., \& Major, C. H. (2013). Qualitative Research: The essential guide to theory and practice. Routledge.

Schiffman, L. G., Kanuk, L. L., \& Hansen, H. (2012). Consumer behavior: An European outlook (2nd ed.). England: Pearson Education Limited.

Schreier, M. (2012). Qualitative content analysis in practice. CA: Sage.

Sigma Research. (2017, Agustus 02). Tren dan Perilaku Pasar Kosmetik Indonesia Tahun 2017. Consumer Research, Survey Kosmetik Indonesia. 
Teddlie, C., \& Tashakkori, A. (2003). Major issues and controversies in the use of mixed methods. In A. Tashakkori, \& C. Teddlie, Handbook on mixed methods in the behavioral (pp. 3-50). Thousand Oaks: CA: Sage.

Thompson Reuters. (2016). State of the Global Islamic Report 2016/17. Dubai: Thompson Reuters.

US Commercial Services. (2015). Cosmetics \& Toiletries Market Overviews 2015. US Department of Commerce.

Vaismoradi, M., Turunen, H., \& Bondas, T. (2013). Content analysis and thematic analysis: Implications for conducting a qualitative descriptive study. Nursing and Health Sciences, 15, 398-405.

Van Osselaer, S. M., \& Alba, J. W. (2000). Consumer learning and brand equity. Journal of Consumer Research, 27(1), 1-16.

Washburn, J. H., \& Plank, R. E. (2002). Measuring brand equity: An evaluation of a consumer-based brand equity scale. Journal of Marketing Theory and Practice, 101(1), 46-62.

Wood, L. (2000). Brands and brand equity: Definition and management. Management Decision, 38(9), 662-669.

Zuraya, N. (2016, Pebruari 16). Republika. Retrieved November 30, 2018, from www.republika.co.id: https://www.republika.co.id/berita/dunia-islam/islamnusantara/16/02/16/o2m324383-kesadaran-masyarakat-indonesia-mengonsumsiproduk-halal-masih-rendah 